\title{
A REVIEW OF THE LATERAL LINE SENSORY SYSTEM IN PSAMMOSTEID HETEROSTRACANS
}

\author{
DAVID K. ELLIOTT \\ Northern Arizona University, Flagstaff, AZ 86011, USA.david.elliott@nau.edu \\ ELGA MARK-KURIK \\ Tallinn University of Technology, 10143 Tallinn, Estonia. kurik@gi.ee
}

\begin{abstract}
The heterostracan lateral line system consists of a network of closed canals within the dermal plates that open to the surface by pores. This system is well known in some heterostracans, where it consists of a symmetrical arrangement of canals, but is known in only a few psammosteids, where the pattern is more irregular. A new obrucheviid from the Late Devonian of arctic Canada shows a typical heterostracan pattern, but the canals were held in open surface grooves, generally considered a derived feature in heterostracans. A second new arctic species similar to Psammosteus features a reticulate dorsal canal system with the canals delineating polygonal areas and the normal pattern of longitudinal and transverse canals lost. This pattern is unique within heterostracans and may be a derived feature related to a need for increased sensory function. The canals were situated below the surface tesserae and are thus only exposed by abrasion. Species with small tesserae have canals enclosed in tubes and their position may be indicated on the surface as ridges formed by the presence of small, elongated tesserae. Those with large tesserae have canals enclosed within the spongy layer of the dermal plate. Some species of Psammosteus may have had a double sensory canal system in the dorsal plate, with one system deeper in the spongy layer, the other close to the surface of the plate but still under the ornament. Behind the carapace the sensory canal system is situated directly below the scales and connects to the surface with short branches. These penetrate the scales, which are thin and have no basal layer.
\end{abstract}

Key words: Heterostracans, psammosteids, lateral line canals, Devonian.

RESUMO - O sistema da linha lateral em heterostráceos consiste de uma rede de canais fechados dentro das placas dérmicas que abrem-se na superfície através de poros. O sistema é bem conhecido em heterostráceos, onde ele consiste de um arranjo simétrico de canais, mas é conhecido em apesas alguns poucos psammosteídeos, onde o padrão é irregular. Um novo obrucheviídeo do Devoniano Superior do Ártico canadense, apresenta um típico sistema de canais heterostráceo, mas os canais conservavam-se em valetas abertas à superfície., um caráter geralmente considerado derivado em heterostráceos. Uma segunda nova espécie ártica similar a Psammosteus, apresenta um sistema de canais dorsais reticulado, no qual delineam áreas poligonais e o padrão normal de canais longitudinais e transversais está perdido. Esse padrão é único dentre os heterostráceos e pode ser uma característica derivada relacionada a necessidade de um aumento da função sensorial. Os canais situavam-se abaixo das tesseras e consequentemente estão expostos somente por abrasão. Espécies com tesseras pequenas tem canais envolvidos por tubos e sua posição pode ser indicada na superfície pela presença de pequenas tesseras alongadas. Espécies com tesseras grandes têm canais encapsulados dentro da camada de osso esponjoso da placa dérmica. Algumas espécies de Psammosteus podem ter tido um sistema duplo de canais sensoriais na placa dorsal, com um sistema situado mais profundamente na camada esponjosa e o outro próximo à superfície, mas ainda abaixo da ornamentação. Atrás da carapaça, o sistema do canal sensorial está situado diretamente abaixo das escamas e conecta-se à superfície através de ramificações curtas. Essas penetram nas escamas, que são finas e não têm camada basal.

Palavras-chave: Heterostráceos, psammosteídeos, canais da linha lateral, Devoniano.

\section{INTRODUCTION}

The lateral line system in fishes consists of a series of surface or near surface canals and tubes containing the neuromasts. These sensory organs are sensitive to disturbances in the water and provide the fish with information that contributes to obstacle avoidance and orientation of the body relative to currents. Hagfish and lampreys do not have neuromasts in canals although they do tend to be linearly arranged. In heterostracans the sensory canal system consists of a series of closed canals in the cancellous layer of the dermal bone opening to the surface by pores and is 
usually only visible if the surface of the plate has been eroded. In cyathaspidids and pteraspidids the system is well known and usually consists of an almost diagrammatically simple pattern of longitudinal canals and transverse commissures (Figure 1A, D), although in some species it can be greatly elaborated (Figure 1B, C). Trends can be recognized in the arrangement of the system, with short sections of canal in earlier cyathaspidids evolving into a more connected system in later forms and then culminating in the completely connected system of the pteraspidids (Figure 1A, D). Details of the arrangement of these canals has been used in the identification of both cyathaspidid and pteraspidid species (Denison, 1964; Blieck, 1984), but has not proved useful within the psammosteids because until recently the sensory canal system was known mainly from the dorsal plates of just a few Middle and Late Devonian forms such as Psammolepis, Psammosteus and Tartuosteus (Halstead Tarlo, 1964, 1965; Obruchev \& MarkKurik, 1965, 1968). In these forms two medial dorsal canals and 1-3 cross-commissures, and rarely lateral dorsal canals are present. Gross (1963:fig. 10) identified radial ridges of dorsal and ventral plates of the Early Devonian Drepanaspis gemuendenensis as sensory line canals, however, Obruchev and Halstead Tarlo did not agree with the interpretation of these structures, as they were too symmetrical and situated on the visceral surface of the plates (Obruchev \& Mark-Kurik, 1965:43). Although canals are not generally known from the other plates the orbital plates of Psammolepis paradoxa and Psl. undulata and the pineal plate of Psammolepis (?) sp. reveal several narrow and short radial grooves. The discovery of sensory lines in a new Late Devonian obrucheviid psammosteid (Elliott et al., 2004) and another new species, both from the Canadian Arctic, is significant in adding to the limited current information on this group.

Abbreviations. CMN-NUFV, National Museum of Canada, Ottawa; Pi, Institute of Geology, Tallinn University of
Technology; PIN, the Palaeontological Institute, Russian Academy of Sciences, Moscow.

\section{NEW INFORMATION ON THE SENSORY CANAL PATTERN}

\section{Drepanaspis}

Gross (1963: figs. 1, 10) identified radial ridges in the dorsal and ventral plates in the Early Devonian psammosteid Drepanaspis gemuendenensis Schlüter as sensory line canals. Obruchev and Halstead Tarlo did not agree with the interpretation of these structures, as they were too symmetrical and situated on the visceral surface of the plates (Obruchev \& Mark-Kurik, 1965:43). However, a specimen in the collections of the Institute of Geology, Tallinn (Pi 297), from the Odenspiel quarry, Rhineland, Germany that contains two incomplete dorsal plates, two branchial plates and several fragments of Drepanaspis gemuendenensis shows features suggesting that Gross could be correct. One of the dorsal plates, which is rather convex (more than $1 \mathrm{~cm}$ high) and approximately $12.5 \mathrm{~cm}$ wide, has on its visceral side two subparallel longitudinal ridges 3 and $4 \mathrm{~cm}$ long, respectively. The ridges are somewhat asymmetrical, shallow and are in some places divided into two parts by a fine groove. The structure of the ridges coincides with that given by Gross (1963:137). Two more poorly preserved ridges are also visible in the right lateral portion of the plate. The longitudinal canals correspond to the sensory canals $\mathrm{dc}_{1}$, and the laterally situated ones to $\mathrm{dc}_{3}$ and $\mathrm{dc}_{4}$ as illustrated by Gross (1963:fig. 1P). It is notable that the Drepanaspis remains from Odenspiel, preserved in hard gray argillaceous siltstone are less deformed than those from the Hunsrück Shale. The dorsal plates are very thin (less then $1 \mathrm{~mm}$ ) but it can be seen that the
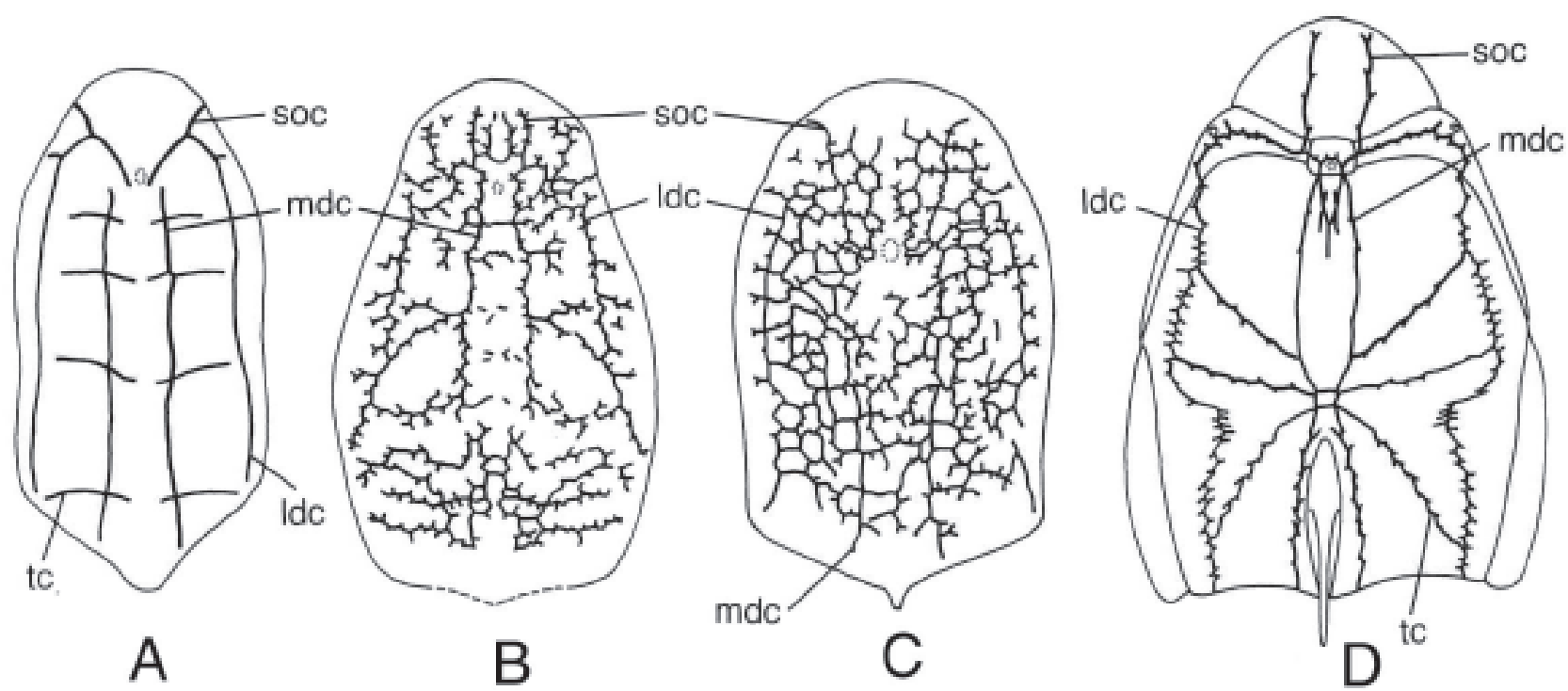

Figure 1. Dorsal lateral line sensory canal systems of heterostracans. A, Poraspis polaris; B, Dikenaspis yukonensis; C, Irregulareaspis complicate; D, Stegobranchiaspis baringensis; (A-C from Denison 1964, D from Elliott 1983). Abbreviations: Idc, lateral dorsal canal; mdc, median dorsal canal; soc, supraorbital canal; tc, transverse commissure. Not to scale. 
sensory line canals were situated in the plate above the smooth and extremely thin basal layer.

\section{New Canadian obrucheviid}

Obruchevia is a derived psammosteid from the Frasnian of the Novgorod Region, NW Russia. The plates are thick and lack any surface tesserae but the external surface of the bone is strengthened by the addition of pleromic dentine. No sensory canals have been reported for this genus (Obruchev, 1941), however, material of a new obrucheviid Perscheia from the Frasnian of southern Ellesmere Island, Canadian Arctic, does show sensory canals as shallow grooves in the surface of the dorsal plate (Elliott et al., 2004). Although the specimens are fragmentary (Figure 2B, C) the system can be reconstructed for the posterior part of the plate and shows the presence of paired medial and lateral longitudinal canals joined by at least one commissure (Figure 3B). Lateral dorsal canals are rarely seen in psammosteids (Figure 4) and their presence here may be a function of the large size of the dorsal plate in this species. The presence of the system as open grooves is also unusual although not unexpected in a species in which the surface covering of dentine tubercles is missing. An intermediate stage can be seen in Traquairosteus pustulatus, a Frasnian species from Scotland in which the outer surface of aspidin is thrown up into conical mounds, each surmounted by a small crenulated dentine tubercle, which are thus very sparsely distributed (Tarlo, 1961). In the holotype (BM P.8297; Halstead Tarlo, 1965:fig.17:1) two canals can be seen as open grooves on the surface indicating that as the dentine tubercles were reduced the canals became exposed and were only covered by the dermis.

\section{New Canadian Psammosteus?}

A partial dorsal plate of a new psammosteid similar to Psammosteus from the Frasnian of southern Ellesmere Island (Figures 2A, 3A) shows a pattern of sensory canal grooves exposed by the loss of the dentine tubercles to erosion. The left anterior part of the plate is preserved and shows a reticular pattern of grooves in which what appear to be paired medial canals anteriorly are connected laterally and posteriorly to canals that delineate large polygonal areas that extend laterally to the edges of the plate. Fragments of dorsal plates of Psammosteus megalopteryx illustrated by Halstead Tarlo (Tarlo, 1961:fig. 4; Halstead Tarlo, 1964:fig. 13) also show a pattern of branching and connecting grooves that seems to indicate a more complex pattern than is usual in psammosteids, however, he reconstructed these as parts of a more typical branching system.

This system is quite unlike that reported for other psammosteids (Figure 4), or for typical cyathaspidids or pteraspidids (Figure 1). However, in the cyathaspidid Dikenaspis (Figure 1B) the canal system has become greatly branched and in some cases these branches have joined to form polygonal areas. A further stage is reached in Irregulareaspis (Figure 1C) in which the branching has become so complex that the main canals are difficult to recognize and the system has become a network of polygonal areas. The pattern shown in the anterior part of the dorsal shield of Irregulareaspis does show a number of points of similarity with that in the psammosteid particularly in the shape and orientation of the polygonal areas. No reasons have been suggested for such a complex system in Irregulareaspis and the presence of a similar network in the new psammosteid is even more difficult to explain, as psammosteids in general appear to have a poorly developed sensory canal system (Figure 4). Given that the lateral line system provides information about local water turbulence, enabling the animal to sense its surroundings, a more complex system such as that developed by the new Psammosteus? might indicate a movement into a more turbulent environment or the development of a new method of feeding that required a greater sensitivity to movement in its surroundings.

\section{Juvenile psammosteids}

Two dorsal plates exemplify the sensory canal system of juvenile psammosteids. One of them, belonging to Tartuosteus maximus (Obruchev \& Mark-Kurik, 1968:fig. 3A) shows very poorly preserved and short medial dorsal canals and three commissures, the posterior ones forming a pair. In the dorsal plate of a juvenile Psammosteus bergi (Figure 4D) that is slender and about half the size of a large individual (Figure 4E), the canals form an irregular cross-like configuration. No lateral dorsal canals are present.

The dorsal plates of adult Psammolepis proia (Figure 4A) and Psl. undulata (Lyarskaya, 1971:fig. 4; Obruchev \& Mark-Kurik, 1965:fig. 170) are narrower anteriorly. The anterior portion of the same plate of a comparatively younger individual of $P$ sl. undulata (Figure 4B) is still narrower. In these plates the commissures almost reach the lateral margins of the plate and no space is left for the lateral dorsal canals. The case could be similar in Psammosteus species with a comparatively narrow anterior portion, such as $P s$. praecursor and Ps. livonicus (Figure 4C, F). In contrast to this arrangement the dorsal plate of Ps. bergi (Figure 4E) is wide anteriorly and includes the lateral dorsal canals. In the other cases just indicated the lateral canals might have run in the tesserated bands lateral to the dorsal plate.

The plate of Psl. undulata in the Tallinn collection (Pi 247) that was erroneously identified by Halstead Tarlo (1964:fig.12A; 1965:fig. 32A) as a ventral plate is actually a juvenile dorsal plate (Figures 4B, 6A-C). Another error in Halstead Tarlo's monograph concerns the identification of a dorsal plate of $P$ sl. proia with an exposed sensory line system as that of Tartuosteus giganteus (Gross) (Halstead Tarlo, 1964:fig. 12B; 1965:fig. 24A). The plate and the other one with ornament (Halstead Tarlo, 1965:fig. 24B) have tesserae, not known in the large armour plates of Tartuosteus species.

\section{Parallel canals}

One more recently discovered character in the sensory line system of psammosteids is the occurrence of parallel paired canals, e.g. in Psl. undulata in which short parallel sections of sensory lines occur at the distal ends of commissures ( Figures 4B; 6B, C). A section of a parallel line 

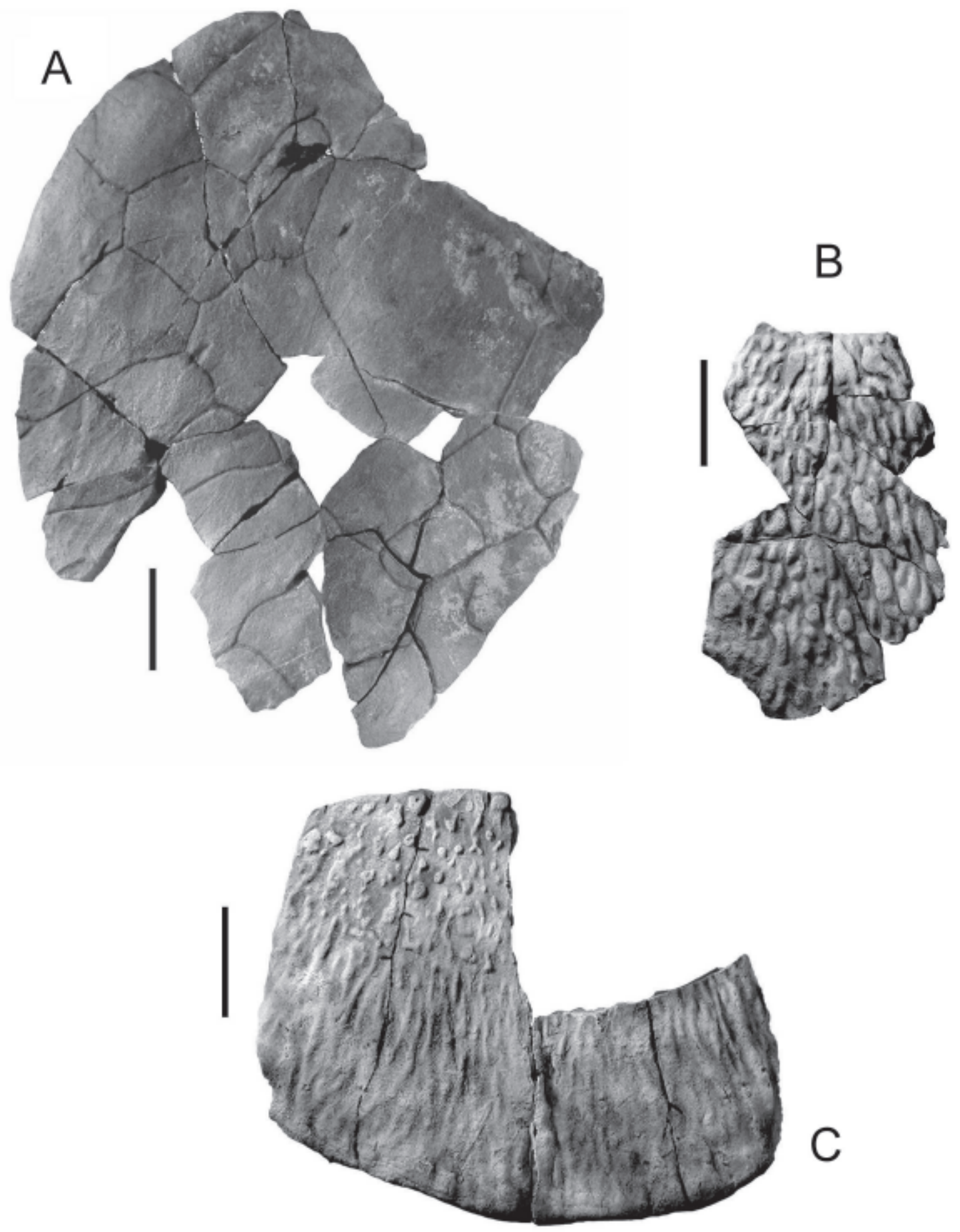

Figure 2. Lateral line system of new psammosteids from the Late Devonian of the Canadian Arctic. A, left anterior part of the dorsal plate of a psammosteid similar to Psammosteus (CMN-NUFV108) showing a reticulated canal system exposed by the removal of the surface tesserae (see Figure 3A for an explanatory drawing of this specimen); B-C, obrucheviid Perscheia showing sensory system of open grooves on the surface of the dorsal plate; B, CMN-NUFV103, fragment of dorsal plate with a transverse canal running horizontally across the central part; C, CMN-NUFV101, posterior part of a dorsal plate with a cross commissure forming the upper left boundary and a part of the median dorsal canal running from the central part of that edge towards the posterior edge of the plate (see Figure 3B for a reconstruction). Scale bars $=50 \mathrm{~mm}(\mathbf{A}), 100 \mathrm{~mm}(\mathbf{B}, \mathbf{C})$. 
occurs also in Psammosteus bergi (Figure 5E). In Psl. undulata, a juvenile dorsal plate was described by Lyarskaya (1971:fig. 5), the arrangement of the medial dorsal canals and a pair of long cross commissures coinciding with those in the specimen figured in the present paper (Figure 4B). Lyarskaya (1971:fig. 4) figured two medial canals in the dorsal plate of an adult $P$ sl. undulata.

\section{POSITION OF CANALS WITHIN PLATES}

Generally psammosteid sensory canals, situated just under the tubercles, become visible only in rare cases when the ornament is abraded and the upper surface of the spongy layer is exposed, e.g. in the dorsal plates of Tartuosteus maximus Mark-Kurik, Psammolepis proia Mark-Kurik (Figure 4A), and Psl. undulata (Figure 4B). The latter two Psammolepis species had comparatively large tesserae, but in Psammosteus with generally smaller tesserae, tubes, enclosing canals and situated below the tesserae were exposed by wear as e.g. in Psammosteus bergi (Obruchev). The dorsal plate of Ps. bergi (Figure 5A, B) and several of its fragments (Figure $5 \mathrm{C}-\mathrm{E}$ ) particularly reveal the structure of the sensory lines. One of them (Figure 5C), was earlier figured by Obruchev \& Mark-Kurik (1965:fig.187; pl.64, fig.2). Halstead Tarlo (1965:fig.28A) also figured the specimen but used the generic name Yoglinia (Obruchev, 1943), which was considered to be a junior synonym of Psammosteus
(Obruchev \& Mark-Kurik, 1965: 215). The specimens of $P$ s. bergi that have lost practically all their ornament have both open grooves and partly broken aspidin tubes raised somewhat above the bare surface of the plate or its fragments. One of the fragments shows a short section of a parallel groove (Figure 5E, indicated by a white arrow). The dorsal plate of a large individual of Ps. bergi (Figures 5A, B) has one more remarkable feature. In its posterior left portion the middle commissure crosses a short ( $8 \mathrm{~mm}$ long) section of the lateral dorsal canal. This canal section is situated deeper in the aspidin layer of the plate (the crossing point is indicated in Figure 5B by a white arrow). The crossing grooves, actually canals, point to the presence of a double canal system, supposed to exist also in another representative of the genus Psammosteus (Ps. megalopteryx), and otherwise only known in a quite different group of heterostracans, the amphiaspids (see the discussion below).

In unworn shields of Psammosteus small elongated tesserae mark the position of sensory canals in the plates, e.g. in Ps. praecursor Obruchev. In this species the sensory canal pattern appears to be more developed than figured earlier (Obruchev \& Mark-Kurik, 1968:fig.3H; Figure 4C). In the dorsal plate of Psammosteus livonicus Obruchev (Figure $4 \mathrm{~F}$ ) in which almost all the tesserae have been lost, the canals exposed from above by abrasion are visible as narrow ridges of spongy aspidin with a groove in the middle and slightly raised above the surface of the plate. The canal pattern

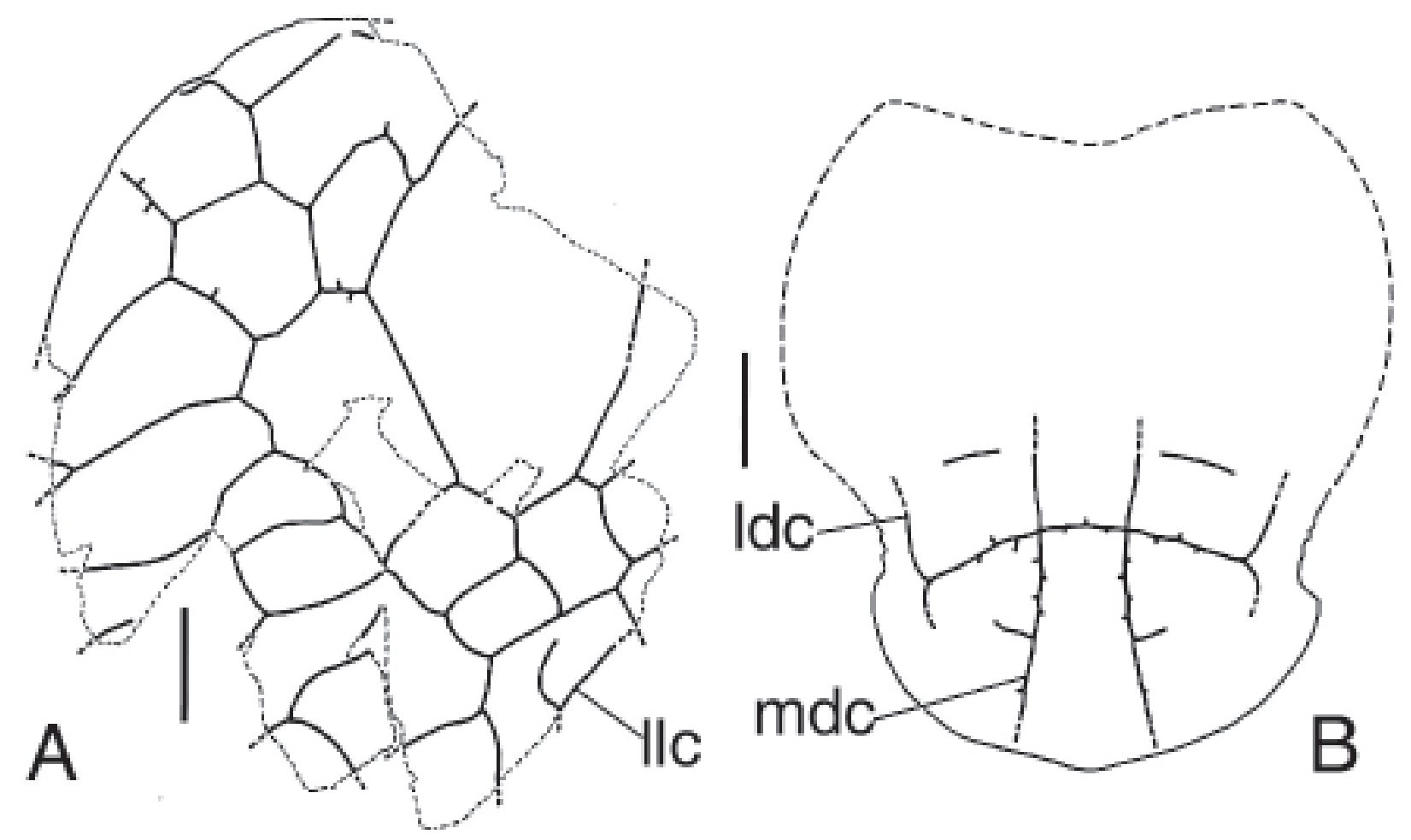

Figure 3. Lateral line system of new psammosteids from the Late Devonian of the Canadian Arctic. A, left anterior part of the dorsal plate of a psammosteid similar to Psammosteus (CMN-NUFV108) showing the reticulated canal system (same specimen as Figure 2A), scale bar $=50 \mathrm{~mm}$; B, reconstruction of the canal system in the posterior part of the dorsal plate of the new obrucheviid Perscheia (Elliott et al., 2004), scale bar = $100 \mathrm{~mm}$. Abbreviations: Idc, lateral dorsal canal; llc, lateral commissure; mdc, median dorsal canal. 


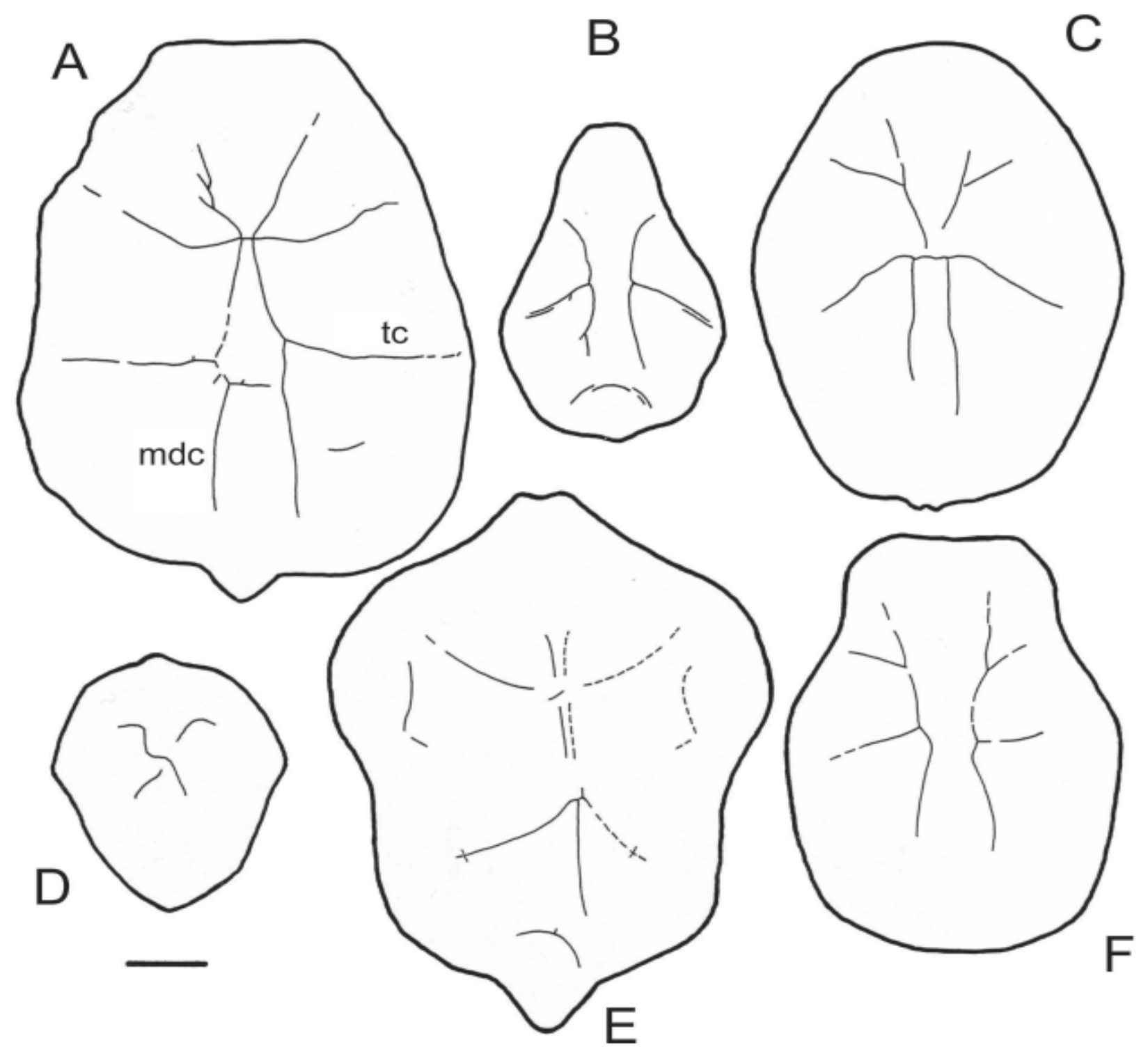

Figure 4. Lateral line pattern in the dorsal plates of psammosteids. A, Psammolepis proia Mark-Kurik, adult plate, Pi 123; B, Psl. undulata (Ag.), juvenile plate, Pi 247; C, Psammosteus praecursor Obr., adult, Pi 164; D, E, Psammosteus bergi (Obr.); D, juvenile, Pi 912; E, adult, Pi 739; F, Ps. livonicus Obr., adult, Pi 722. Abbreviations: mdc, median dorsal canal; tc, transverse commissure. Scale bar $=50 \mathrm{~mm}$ (modified after Obruchev \& Mark-Kurik, 1968).

appeared to be more complete than figured earlier (Obruchev \& Mark-Kurik, 1968:fig.3D) and, in general, resembles that in Ps. praecursor (Figure 4C).

Two medial canals situated under rows of smaller tesserae can be observed in the dorsal plate of a large individual of Psammosteus megalopteryx (Trautschold) (Obruchev \& Mark-Kurik, 1965:pl.80, fig.2), a phenomenon visible in the dorsal plate of Ps. praecursor (Figure 6D-F). That the sensory canal pattern in $P s$. megalopteryx was actually more complicated was demonstrated by Halstead Tarlo (1964:fig.13) who figured worn dorsal plate fragments with medial and lateral dorsal canals and several transverse commisures and/ or canal branches. In Ps. megalopteryx another variant of the canal structure has been described. According to Obruchev in a plate fragment of this psammosteid the sensory canals formed shallow and very narrow branching ridges on tesserae (Obruchev \& Mark-Kurik, 1965:pl.78, fig.2; Figure 5F). Thus, it is not excluded that Ps. megalopteryx could also possess a double sensory canal system: an upper one in the tesserae and the lower one under the tesserae in the upper part of the spongy layer of the dorsal plates. As shown by the Canadian Arctic Psammosteus? specimen the lower system may be more complex and form a reticulated pattern. If the double sensory line system really existed in $P s$. megalopteryx, and also in Ps. bergi, then it could be compared with that in the amphiaspid Siberiaspis plana 

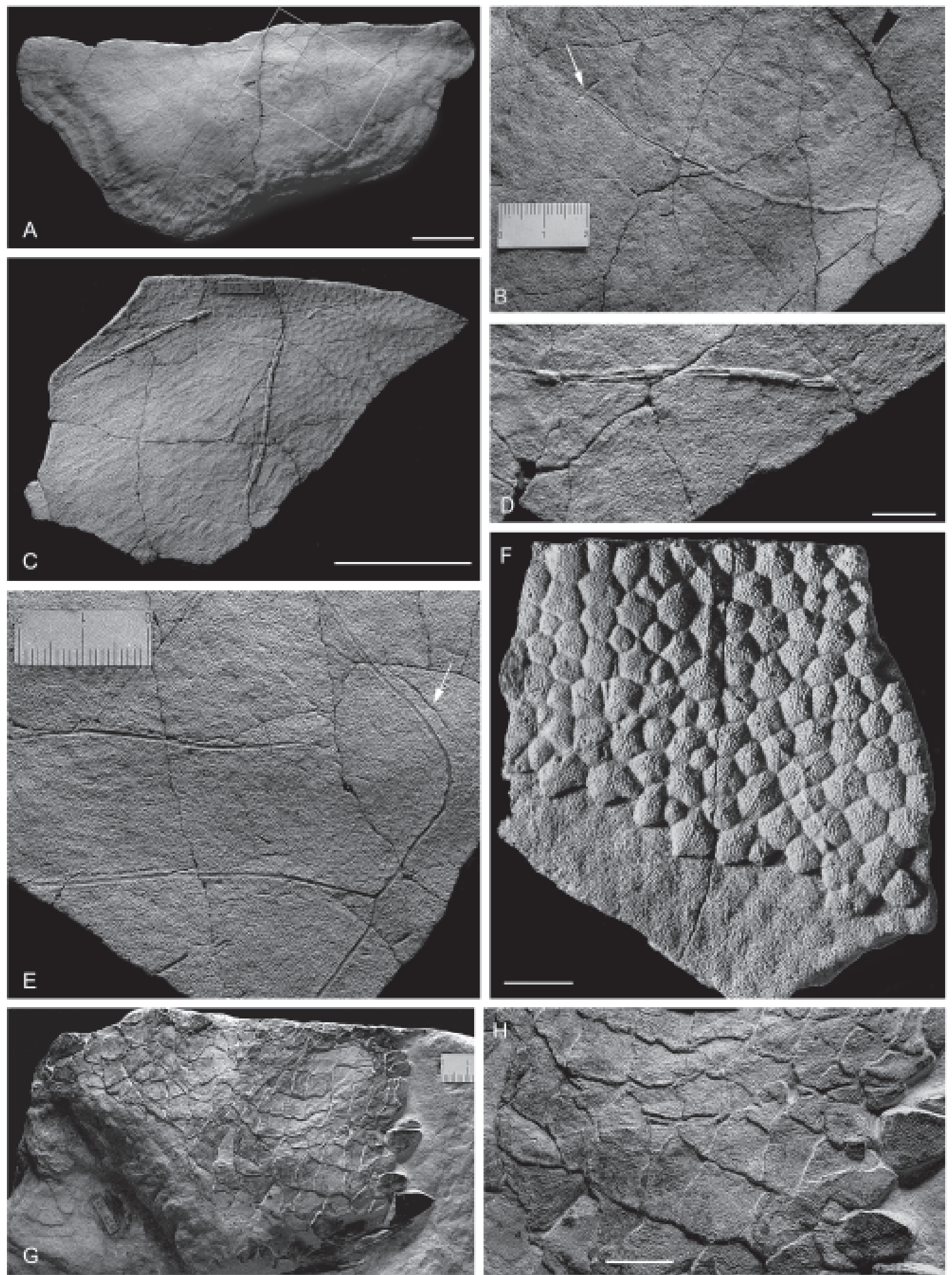

Figure 5. Sensory canals in various psammosteids. A-E, Psammosteus bergi (Obr.), dorsal plate (A, B, Pi 739) and dorsal plate fragments (C, Pi 161; D, Pi 188; E, Pi 727); A-D, showing sensory canals enclosed in tubes (note that the area delineated in A indicates that shown in $\mathrm{B}$, and that the arrow in $\mathrm{B}$ shows the point at which a more surface canal crosses one deeper in the plate); $\mathrm{E}$, showing parallel development of canals (indicated by the arrow). Karksi, Estonia; Middle Devonian, Burtnieki Formation; F, Psammosteus megalopteryx (Trautschold), fragment of dorsal plate PIN 220/541, showing surface pattern of branching ridges. Stolbovo, Russia; Upper Devonian, Porkhov Beds; G-H, Schizosteus striatus (Gross), fragment of squamation, Pi 416, showing lateral line canal. Gorodenka, Estonia; Middle Devonian, Narva Formation. Scale bars $=50 \mathrm{~mm}(\mathrm{~A}, \mathrm{C}), 10 \mathrm{~mm}(\mathrm{D}, \mathrm{F}, \mathrm{H})$. 

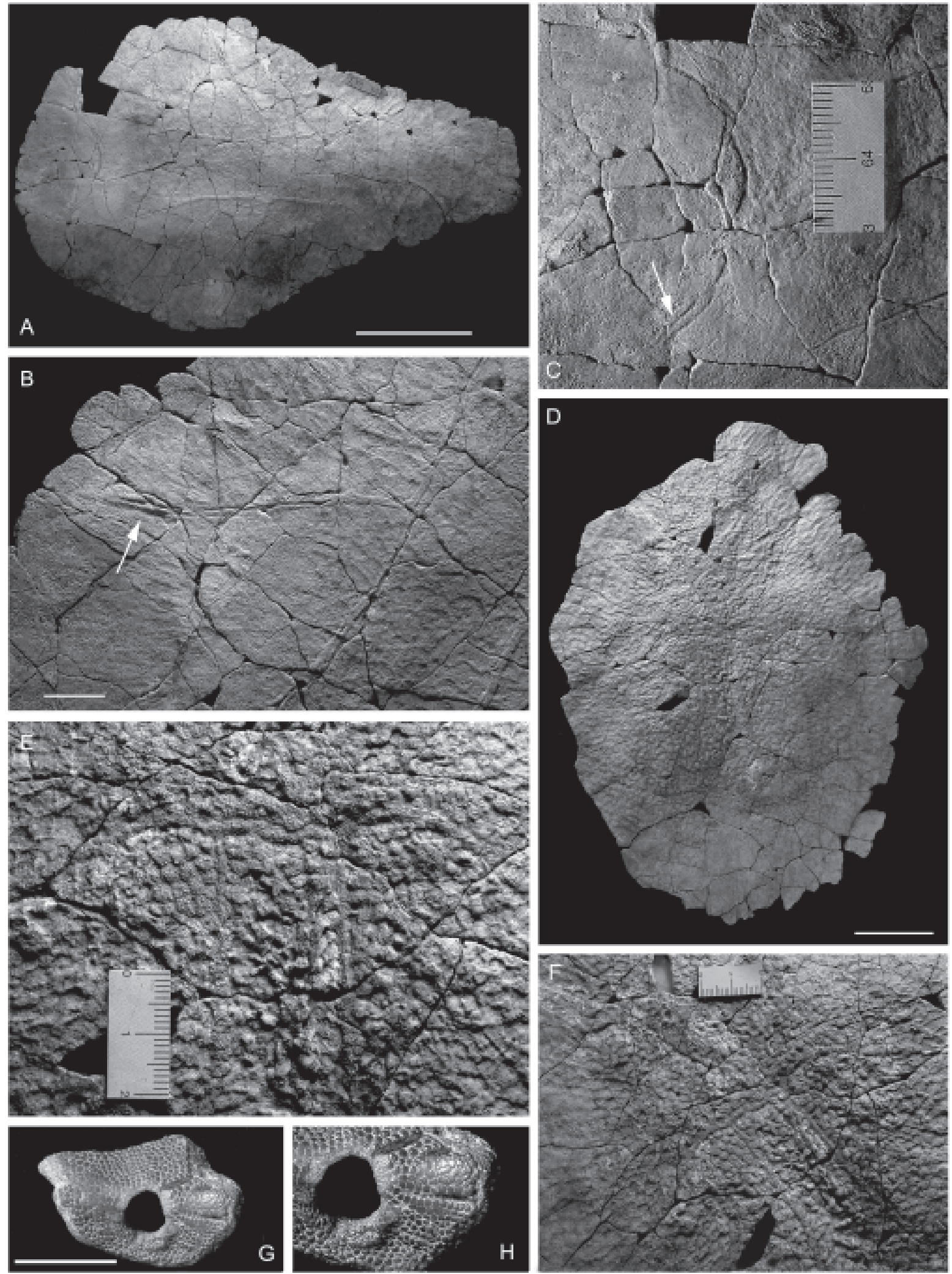

Figure 6. Sensory canals in various psammosteids. A-C, Psammolepis undulata (Ag.), juvenile dorsal plate, Pi 247, showing the canal system (A) and details of the development of parallel paired canals (indicated by arrows in B and C). Kuke, Latvia; Middle(?) Devonian, Amata Formation; D-F, Psammosteus praecursor Obruchev, dorsal plate, Pi 164, showing the two medial canals under rows of smaller tesserae. Vastseliina, Estonia.: Middle(?) Devonian, Amata Formation; G, H, Psammolepis paradoxa Agassiz, left orbital plate, Pi 246, showing radial grooves considered to be part of the sensory canal system. Straupe, Latvia; Middle Devonian, Gauja Formation. Scale bars $=50 \mathrm{~mm}(\mathrm{~A}, \mathrm{D}), 10 \mathrm{~mm}(\mathrm{~B}, \mathrm{G})$. 
Obruchev, described in detail by Novitskaya (1971:fig.7; 1983:fig. 37). In Siberiaspis the upper system was developed as open grooves on the surface, and the lower one as canals within the carapace, however, it is worth noting that the lower system was complex and branching as appears to be the case in Psammosteus. Novitskaya (1983:279) remarked that she discovered the double sensory line system in many forms, not only in Siberiaspis but also in Argyriaspis, Olbiaspis, Angaraspis, and Gabreyaspis.

Although open grooves were earlier supposed to occur in smaller plates of Psammolepis, a recent study of the orbital plate of Psl. paradoxa shows these could be due to the fossilization process. One of these narrow but deep grooves is partly covered with a row of small tubercles and it is suggested that these tubercles could form a "roof" over the canals in the orbital plate (Figure $6 \mathrm{G}, \mathrm{H}$ ) so that they occur in fact occur below the surface of the plate.

The structure of the sensory line system of the body behind the carapace is somewhat different (Mark-Kurik, 1993) from that of the carapace. A large fragment of squamation in Schizosteus striatus shows that the sensory canal was situated in soft tissue immediately under the scales leaving a shallow groove on their visceral surface (Mark-Kurik, 1993:fig. 2; Figure 5G, H). Short branches connected canals with the external surface of the body. Scales in psammosteids were much thinner than the armor plates and had no compact basal layer.

\section{CONTRIBUTION TO AN UNDERSTANDING OF RELATIONSHIPS}

There has been some discussion of the position of psammosteids within the heterostracans with the traditional view being that they are the most derived member of the Pteraspidiformes (see e.g. Janvier, 1996). Recent work by Pernègre (2002) suggests that they may be more correctly sited within the Pteraspidiformes as a derived member of the Pteraspidina and sister group to Doryaspis, however, it should be noted that a number of psammosteid features indicate that the traditional view may be the correct one. In particular the squamation of psammosteids consists of a large number of rows of flank scales as is the case in pteraspids but not in Doryaspis, and the position, pattern, and number of lateral plates in the carapace of psammosteids differs significantly from those in Doryaspis. Although this study of the sensory canal system in psammosteids provides new morphological information it does not at present shed any additional light on the relationships of the psammosteids which must come as part of a complete review of the Pteraspidiformes, a study that is currently overdue.

\section{CONCLUSIONS}

Until recently the sensory canal system was known in psammosteid heterostracans mainly from the dorsal plates of a few Middle and Late Devonian forms such as Psammolepis,
Psammosteus and Tartuosteus in which two medial dorsal canals and 1-3 cross commissures, and rarely lateral dorsal canals are present. This review of current information provides the following new information:

Gross (1963:fig. 10) identified radial ridges of dorsal and ventral plates of Drepanaspis gemuendenensis as sensory line canals. Although this identification was not supported at the time (Obruchev \& Mark-Kurik, 1965:43) new specimens confirm the original interpretation.

The discovery of sensory lines in the new Late Devonian obrucheviid Perscheia psammosteid from the Canadian Arctic (Elliott et al., 2004) shows that canals were present in open surface grooves and that lateral dorsal canals were present. No canals are reported for Obruchevia although open surface grooves are also known in the related Traquairosteus (Psammosteus) pustulatus (Halstead Tarlo, 1965).

A dorsal shield of Psammosteus? from the Canadian Arctic shows a system of canals that ramifies and branches to form a reticulate pattern. A similar pattern had been reported for Psammosteus megalopteryx (Halstead Tarlo, 1964:fig. 13) although from plate fragments only.

Where exposed by abrasion the canals can be seen enclosed by tubes and situated below the tesserae as in Psammosteus bergi. In unworn shields small elongated tesserae mark the position of sensory canals on the plates, e.g. in Psammosteus praecursor.

Another variant is known in Psammosteus megalopteryx in which sensory canals form shallow branching ridges on tesserae (Obruchev \& Mark-Kurik, 1965:pl. 78:2). As canals are often also present in deeper parts of the carapace this suggests that psammosteids may have possessed a double sensory canal system as has previously been reported in the amphiaspids.

The sensory line system of the body behind the carapace was situated immediately under the scales (Mark-Kurik, 1993:fig. 2). Short branches connected canals with the external surface of the body. Scales in psammosteids were much thinner than the armour plates and had no compact basal layer.

\section{ACKNOWLEDGMENTS}

We wish to thank E. B. Daeschler (Academy of Natural Sciences, Philadelphia) who collected the Canadian material and made it available for study. D. K. E. also acknowledges the receipt of a COBASE grant that supported reciprocal visits with E. M.-K., and support from the Academy of Natural Sciences, Philadelphia for visits to the collections. E. M.-K. thanks the Estonian Science Foundation for supporting her research (Grant 5275). She also sincerely thanks Markus Otto, who in 1989 carried the heavy slab with Drepanaspis remains as a gift to Tallinn. We particularly thank S. Swift (Flagstaff) and G. Baranov (Tallinn) who photographed the material and assembled the photographic figures, and M. Richter who translated the abstract into Portuguese. This manuscript was improved by the helpful comments of A. Blieck and P. Janvier. 


\section{REFERENCES}

Blieck, A. 1984. Les Hétérostracés Ptéraspidiformes, Agnathes du Silurien-Dévonien du Continent Nord-Atlantique et des Blocs Avoisinants. Éditions du Centre national de la Recherche Scientifique. 199 p.

Denison, R.H. 1964. The Cyathaspididae: A family of Silurian and Devonian jawless vertebrates. Fieldiana, Geology, 13:309-473.

Elliott, D.K. 1983. New Pteraspididae (Agnatha, Heterostraci) from the Lower Devonian of Northwest territories, Canada. Journal of Vertebrate Paleontology, 2:389-406.

Elliott, D. K.; Mark-Kurik, E. \& Daeschler, E. B. 2004. A revision of Obruchevia (Psammosteida: Heterostraci) and a description of a new obrucheviid from the Late Devonian of the Canadian Arctic. Acta Universitatis Latviensis, 679:22-45.

Gross, W. 1963. Drepanaspis gemuendenensis Schlüter. Palaeontographica, 121A:133-155.

Halstead Tarlo, L.B. 1964. Psammosteiformes (Agnatha) - A review with description of new material from the Lower Devonian of Poland. I. General part. Palaeontologica Polonica, 13:1-135.

Halstead Tarlo, L.B. 1965. Psammosteiformes (Agnatha) - A review with descriptions of new material from the Lower Devonian of Poland. II. Systematic part. Palaeontologica Polonica, 15:1168.

Janvier, P. 1996. Early Vertebrates. Clarendon Press, Oxford. 393 p.

Lyarskaya, L. 1971. New finds of psammosteid remains from _ventoji Horizon of Latvia. In: A. A. Grigelis (ed.) Palaeontology and Stratigraphy of the Baltic and Byelorussia, 3:97-104. [in Russian]

Mark-Kurik, E. 1993. Notes on the squamation in psammosteids. Modern Geology, 18:107-114.
Novitskaya, L. 1971. Les Amphiaspides (Heterostraci) du Dévonien de la Sibérie. Cahiers de Paléontologie. Éditions du Centre national de la Recherche scientifique: 1-130.

Novitskaya, L. 1983. Morphology of ancient agnathans (heterostracans and the relationship problem of agnathans and gnathostome vertebrates). Transactions of the Palaeontological Institute, Academy of Sciences of the USSR, 196:1-183. [in Russian]

Obruchev, D.V. 1941. Remains of Aspidosteus gen. nov. (Heterostraci) from the Upper Devonian of River Lovat. Travaux de l'Institut Paléontologique, Académie des Sciences de l'Union des Républiques Soviétiques Socialistes, 8 (4):7-22. [in Russian]

Obruchev, D.V. 1943. Yoglinia n.g., latest representative of pteraspids from the Middle Devonian of the Leningrad District. Reports of the Academy of Sciences of the USSR, 41(1):36-38. [in Russian]

Obruchev, D.V. \& Mark-Kurik, E. 1965. Devonian psammosteids (Agnatha, Psammosteidae) of the USSR. Institute of Geology, Academy of Sciences of the Estonian SSR, Tallinn, 304 p. [in Russian]

Obruchev, D.V. \& Mark-Kurik, E. 1968. On the evolution of the psammosteids (Heterostraci). Proceedings of the Academy of Sciences of the Estonian SSR. Chemistry, Geology, 17(3):279-284.

Pernègre, V. N. 2002. The genus Doryaspis White (Heterostraci) from the Lower Devonian of Vestspitsbergen, Svalbard. Journal of Vertebrate Paleontology, 22(4):735-746.

Tarlo, L.B. 1961. Psammosteids from the Middle and Upper Devonian of Scotland. Quarterly Journal of the Geological Society of London, 117:193-213. 